\title{
The Task and Ministry of Peacemaking in Mindanao: Understanding a Peacemaker's Recipe for Peace
}

\author{
Noel G. Asiones ${ }^{1}$ \\ ${ }^{1}$ University of Santo Tomas, Espana, Manila, Philippines \\ Correspondence: Noel G. Asiones, University of Santo Tomas, Espana, Manila, Philippines. E-mail: ngasiones@ \\ ust.edu.ph
}

Received: September 15, 2019; Accepted: October 20, 2019; Published: October 20, 2019

\begin{abstract}
At a time when the role of religion in reducing global conflicts and the authority of its leaders are being questioned, studies that would link religion and conflict may fill in a gap in knowledge. To address this gap, this study seeks to gain an understanding of Orlando Cardinal Quevedo's task and ministry of peacemaking in the long-running conflict in the Southern Mindanao region. Given the recent signing of the Bangsa Moro Organic Law as the highly expected solid basis for a peaceful and prosperous Mindanao, it is timely to look back and pay closer attention to the key role that he played as a peace advocate. To achieve this end, it organized and conducted a content analysis of his writings and interviews about peace and its imperatives. Findings show that his words, firmly rooted in the conflict's historical past and yet open to the realities of the present, encompassed and helped disclose his practical wisdom, consensus-driven approach, and Catholic perspectives of its underlying issues and challenges. The lessons and insights that are uncovered from his writings may serve as a grounded recipe for those who would follow in his footsteps to learn and re-appropriated in a hopefully not an unending task and ministry of peacemaking in today's world.
\end{abstract}

Keywords: consensus-building, content analysis, a fusion of horizons, ministry, Orlando Quevedo, peace, peacemakers, strategies of peacemaking, understanding

\section{Introduction}

The celebrated book Peacemakers in Action: Profiles of Religion in Conflict Resolution narrates and shares the experience of 16 remarkable religious peacemakers hailed as "unsung heroes who have put their lives on the line in conflicts around the world, to help resolve some of the world's horrifying conflicts" (Holbrooke 2007). They are, in the words of former American Ambassador Richard Holbrooke, "stellar examples of religiously motivated peacemakers around the world; each of them is unique, but are all similarly motivated by a shared moral conviction and a religious calling to work until peace and justice are a reality. Holbrooke asserted that their impacts and what they teach about resolving today's conflicts cannot be ignored. In this view, it is a bit a surprise that the book seemed to have overlooked our local peacemakers. If it's any consolation, the book, Mindanao: The Long to Peace and Prosperity, listed one of them in the index even if as a mere footnote (Stephens 2016).

To address the apparent disregard of our own native peacemakers, this study decided to reflect on the peace and peacemaking advocacy of Orlando B. Quevedo, Mindanao's first and lone Cardinal, the archbishop of Cotabato and who is, among the Catholic bishops of the Philippines, widely considered as the most knowledgeable and actively engaged in the quest for peace in the country's second-biggest island (Nan et al. 2001). His constituents call him as the "Cardinal for Peace." As a longtime Mindanawan, he witnessed the destructive effects of the conflict on the people's quality of life, on the one hand, as well as envisioned the collective dream and promise of a long and lasting peace, on the other. Seeing both the lights and shadows of the armed-conflict, he embraced the task of a peacemaker, spoke, and wrote extensively about it during the long process of the search for a principled and negotiated peace now believed to be within arms-reach given the recent signing of the Bangsa Moro Organic Law as the highly expected solid basis for a peaceful and prosperous Mindanao and a watershed in Philippine history. Both moderate Muslims and Christians will most likely feel good about it.

At a time when the role of religion in reducing global conflicts and the authority of its leaders are being questioned, this study seeks to answer one question skeptics like me asked about the practical side of this subfield of Peace Studies and Interreligious Dialogue (Abu-Nimer 2008). Given the deep-seated mistrust, prejudice, bias, resentment, and anger by both parties in the armed-conflict, what can and must a peace advocate like Cardinal Quevedo 
possibly say and/or do? It will be guided by the following more specific concerns: "who is he, what did he say and do, how did he say or do it, and how did he keep going?"

To obtain an empirical answer to these questions, it organized and analyzed the contents of his written communications about peace and peacemaking (Note 1). It is assumed that they encompassed his manifest and latent perspectives of the protracted quest for peace in a region that, because of its rich biodiversity and natural resources, has been called the Land of Promise (Fraenkel and Wallen 2013). To bring it into focus and frame the wealth of data and information gathered, it employed David Myers' four strategies for peacemaking: contact, cooperation, communication, and conciliation (Myers 1994).

This study expects to uncover his perspectives of the challenges and opportunities that have underpinned the said conflict and, perhaps more importantly, of what can and must be done towards the widely shared desire for a just and sustainable peace in the island. Furthermore, it can bring into light the general goals and specific objectives, processes, and contents of the peace negotiations for all stakeholders to consider and appreciate what the German philosopher Hans-Georg Gadamer called the "fusion of horizons" (Gadamer 2004). Nonetheless, suggesting his awareness of the inherent limitations of words, Quevedo admitted that: "It is by our lifestyle and our behavior that we can speak louder, more than words" (Jayewardene 2014). But as Ludwig Wittgenstein once wrote: "Words are deed, used not only to convey thoughts but to perform an activity" (As quoted in David 2018). Thus, in the process of organizing and analyzing the contents of his words, the study can also weave a tapestry of his lived-experience of joys, hopes, and anguish in his ministry or service rendered in the Church as a peace advocate. The lessons and insights it hoped to gain may serve as a grounded recipe for peacemaking which future peacemakers may learn from and re-appropriated in the seemingly unending task and ministry of peacemaking in today's world. Most importantly, it can provide a pattern of meanings into the theoretical and practical implications of peacemaking as, in the words of one author, "the art of the possible."

\section{Findings}

\subsection{Who is He?}

Cardinal Orlando B. Quevedo, OMI has performed his peacemaking task or ministry in the context of the longstanding conflict in the Mindanao region.

I have been a missionary among Muslims for most of my priestly life. I have been a parish priest in Jolo. I taught Muslims and Christians in a Catholic University which now has a predominantly Muslim student population.

As a Catholic leader, a Christian disciple, he is convinced of his task and ministry in the conflict-ridden region:

I am for peace, the peace that God grants to people of goodwill. I am for the peace that God gives through the collaborative work of men and women who work conscientiously for the good of the whole country.

Asked how he would describe himself, he answered: "Simple, I don't demand too many things, and I would like to be with people." (Note 2)

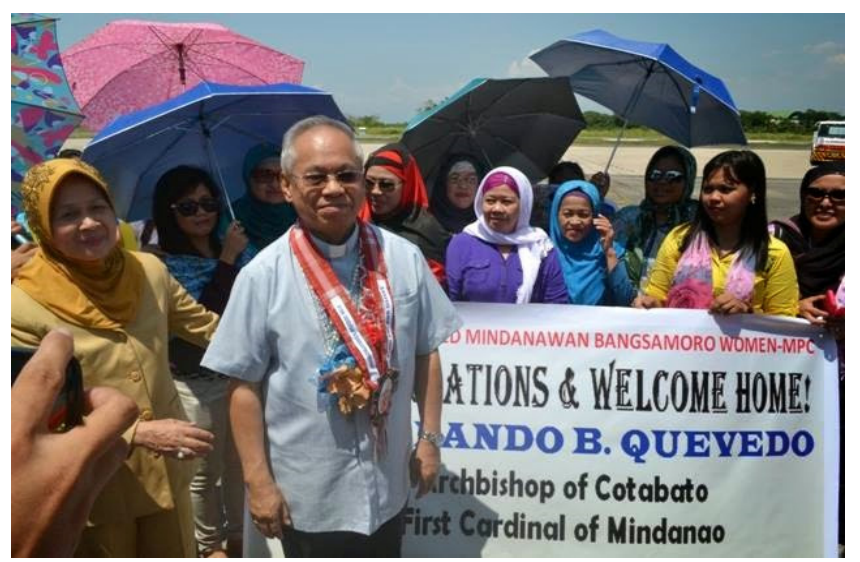

Figure 1. His Excellency Orlando Cardinal Quevedo in a peace-building mission

Source: http://abpquevedo.blogspot.com 


\subsection{What did He Say and Do?}

Framing his words into consideration both of the conflicts' historical roots and present-day realities, Quevedo has spoken and written broadly about the peace process which he described as "a long and tedious, arduous and difficult journey towards peace with many stops and detours?" (Note 3) It is "the most dramatic chapter in the history of the Philippines, a chapter written in blood and tears and nourished in pain and suffering," writes one of the foremost Dominican historians Pablo Fernandez (1994). He also observed that, even during those conflictridden times, there were already intermediaries, diplomats and peace negotiators between the conflicting parties of Muslims and Christians. This only shows that "the island of Mindanao has long been a contested territory in the Philippines, beginning with Spanish colonization 400 years ago and continuing through the recent decades of conflict between the government of the Republic of the Philippines (GPH) and various rebel groups."(Brady, C. et al.2013; Dida, G. R.2012). What has happened in Mindanao across time is too well researched and documented to necessitate further retelling in this study. (Aquino, R. M. 2009; Gowing, P. G., \& Robert, D. M. 1974; Estranero, D. E.et al. 2007; Luga, A. R. 2002; Ong, J. T. et al. 2009; David, R. A. 2003). Suffice it to say that the long and bloody history of Muslim-Christian relations has weighed so heavily on the region's peace and progress that a comprehensive roadmap to a just and lasting peace is so much desired and longed for by its people. Decades of armed conflict between the Philippine government and Muslim organizations made Sulu, one of the poorest provinces in the country (Ong, J.T. et al. 2009).

Quevedo expressed this succinctly when he wrote, "Peace is the only solution to living together, developing a territory together. Peace is the only option." In a paper delivered at the 27th General Assembly of the BishopsBusiness Conference in Taguig, Metro Manila on July 8, 2003, shortly after the Buliok war, he identified the historic injustice perpetrated against Muslim Filipinos as the root cause of the conflict: "Injustice to the Moro Identity; Injustice to Moro Political Sovereignty; and Injustice to Moro integral development." He concludes by saying that:

There is no peace without justice. Peacemaking is about doing the truth and justice, walking in kindness and love, mercy and compassion. This is the way of the heart, the way to a just and lasting peace.

Specifically, he has argued and explained the "substantive questions and lingering doubts" about "the enduring aspirations of the Bangsamoro for self-determination within a limited area." He maintained that for the peace process to prosper two fundamental postulates must be accepted and agreed upon by both sides: the Moro fundamental aspiration for self-determination and the Philippine government's right to national sovereignty and territorial integrity.

At the very beginning of any peace negotiation, there has to be a clear and explicit recognition, mutually accepted: (1) of the national sovereignty and territorial integrity of the Philippines as enshrined in the Philippine Constitution; (2) of the Moro aspiration for self-determination and its concrete realization in a manner in accord with the Philippine Constitution.

He repeatedly argued that "lasting peace can be achieved without sacrificing either right to self-determination or national sovereignty and territorial integrity." Although it seems to run against the popular understanding then, he held on to the view that the two interests are politically acceptable "because the paramount concerns of both parties - territorial integrity and national sovereignty for the government and right to self-determination (RSD) for the MILF" are duly considered. He strongly believed that the Memorandum of Agreement on Ancestral Domain (MOA-AD) crafted by the representatives of the two parties will provide an integral and holistic solution to the conflict and in his own words a "piece of paper" that could very well be a good working basis for lasting peace in Mindanao.

But the MOA-AD, no matter how one looks at it, is a remarkable document. It is a very serious attempt to balance national sovereignty and Bangsamoro aspirations for self-determination and freedom. For this reason, I believe that the MOA-AD can bring lasting peace.

Throwing out this "piece of paper based on mutual misconceptions, prejudices, and misinformation" would cause the demise of the peace process and may most likely lead to an all-out war. (De Jesus 2018).

But to reject the MOA-AD completely based on what it does not say could be a tragedy of incalculable proportion, possibly a death knell to lasting peace. The two panels have painstakingly worked out the peace documents for 11 
long years. I would give them the benefit of the doubt that they have been conscientious in their work, looking out for the interests of their constituencies.

Against those who advocated military or economic solutions to the conflict, he offered a comprehensive, holistic strategy as the most effective way to address a conflict situation that seems to have stood on thin ice:

The road to lasting peace involves a holistic solution, political, economic, cultural, and religious. A political solution, much less a military solution, will not suffice nor will a simple economic one, without the political and cultural/religious.

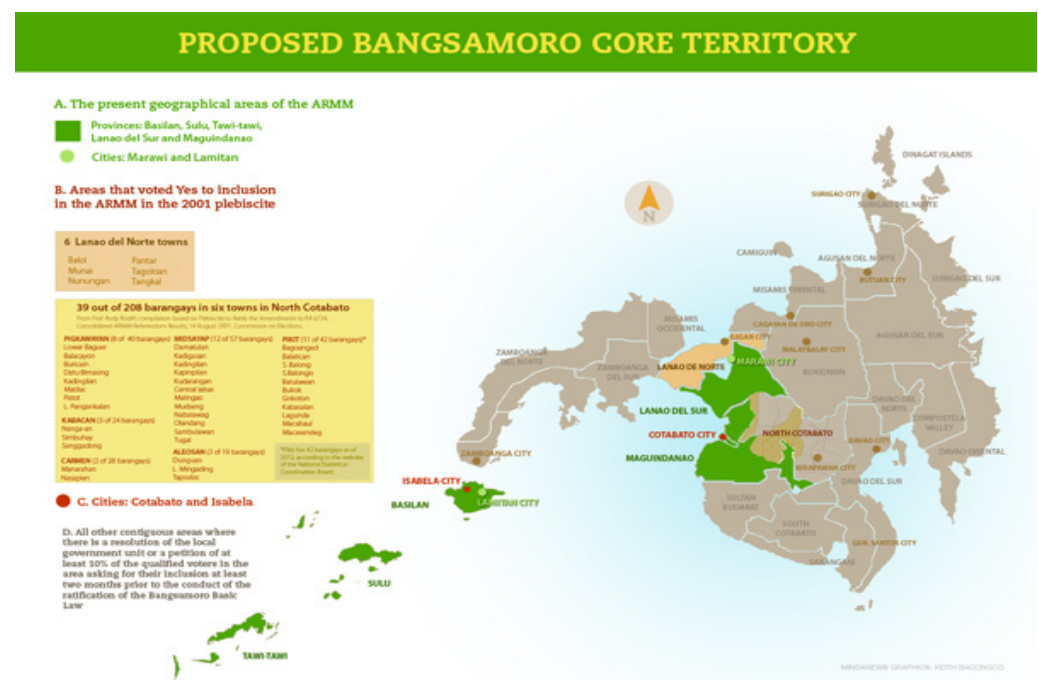

Figure 2. The Site of the Proposed Core Territory of the Bangsa Moro

Source: http://www.mindanews.com > Graphics

This section of the study would now more closely examine the 'how" of Quevedo's peacemaking process through the lens of Myer's four strategies of peacemaking. They are contact, cooperation, communication, and conciliation.

\section{Contact}

This strategy can exert an influence on the adversaries by putting them into close contact to enhance familiarity, mutual acceptance, and reduce mutual mistrust, bias, and prejudices against each other. It presupposes an "equalstatus contact" or contact made on an equal basis on a level playing field. It can be safely said that, at the grassroot or micro level, the moderate Muslims and Christians have managed to live together in mutual tolerance and respect for each other. Both sides are firmly rooted in their religious traditions and yet are respectful and open to their similarities and differences.

I have witnessed a harmonious dialogue of life among the students. Many of our soldiers and high ranking officers studied in our Catholic schools. So, too, did members and leaders of the MILF.

What we have is a beautiful dialogue of life among students, among ordinary people who mixed with Muslims in the market, in the office, at work, in the neighborhood, there's no problem between moderate Muslims and Christians.

(Note 4)

He has been in contact with the Muslims for many years. He remembered that he came from the context of a boy who "grew up in Marbel, Koronadal, Cotabato in the late 40s and early 50s," and whose parents "migrated from the crowded North to the vast and spacious South," and who worked in Mindanao for more than three decades (Mercado 2014; Vitug 2014). The up-close and personal contact with them made a significant impact on his viewpoint and understanding of the conflict.

Through the years I have gained some understanding of the Moro viewpoint.

That has significantly influenced, even altered, my Christian viewpoint." 
Based on these contacts, he expressed the firm belief that, in spite of the political and military conflict in his Archdiocese of Cotabato, peaceful and friendly coexistence between moderate Muslims and Christians is realizable.

We managed to remain friendly towards the Muslims at the grassroots level. Many of the rebel leaders are graduates of our Catholic schools in the archdiocese and some were students of the Notre Dame University where I was the president. So the situation is sometimes over-publicized because the conflict is only in some parts of the Archdiocese of Cotabato and not everywhere. Nonetheless, I am concerned because there is still so much bias and prejudice among Muslims and Christians alike.

The relatively, albeit fragile, peaceful coexistence between the Muslims and Christians ended when, as Quevedo observed, the former started to lose their ancestral lands to the settlers from Northern Philippines (Abreu 2008).

The loss of land was compounded by government neglect of the Moro right to integral development during the Commonwealth and post-independence governments. In all dimensions of human development, political, economic, educational, and cultural, the Moro population continues to lag far behind its Christian Filipino counterparts. The latest national census bears this out in terms of educational improvement, political participation, and economic development. This is truly a tragic plight.

Asked about his plans and hopes as a newly installed cardinal for his archdiocese and the Church as a whole, he replied:

My first concern and hope would be peace; peace in our territory in Central Mindanao; peace in the Archdiocese of Cotabato. Second, I hope to see better harmonious relationships among Christians, Muslims, and indigenous people through interreligious dialogue. My third hope for the people of Cotabato is to see the economic development of all people irrespective of their faiths. But my most primary concern is to inject the dimension of faith, whether in Christians or Islam or indigenous people - to have a common ground for peace and interreligious dialogue based on one's faith. And I would like to press for that.

\section{Cooperation}

This strategy can exert a positive influence on the conflicting individuals or groups by allowing them to work together to face a common predicament or pursue a shared goal (Myers: 283). Thus, an important challenge facing conflicting individuals and groups is to identify and agree on superordinate goals defined by Myers as "goals compelling for all in a group and requiring cooperative effort, and structure cooperative efforts to achieve them." The shared superordinate goal is presumed to outweigh the differences between the parties leading to integrative win-win agreements that reconcile both parties' interests to their mutual benefit.

Now and then, the search for the elusive peace in Mindanao would require a joint and cooperative effort from all stakeholders and constituencies. That being said, the numerous negotiations between the two parties in conflict are a cooperative effort to reconcile the two superordinate goals as crucial to the attainment of a just and lasting peace in the region. Likewise, he proposed to build constituencies to support the peace process believing that to make the peace process works all stakeholders must participate and enjoy their rights to speak and be heard. In the aftermath of the Mamasapano tragedy, he again made this point when he said:

Truly we must seek the truth and justice. This search for truth and the pursuit of justice must be done with objectivity and without prejudgment. We need to gather all the facts from all sides, from civilian witnesses, from combatants on both sides.

Given a long history of bias and mistrust from both parties, cooperation must be built on mutual trust and done in good faith in pursuit of the common good. Thus, efforts for cooperation can and must come from all the stakeholders.

For me, peace is a goal for everybody -- Christians and Muslims, Lumads, peoples of other faiths, government and MILF. Peace is the only solution to living together, developing a territory together. Peace is not acquired overnight. 
There are ups and downs and this Mamasapano tragedy may be the worst of the downs. But if any heart can lift itself out of the pieces of a broken peace, it would be the heart of a sincere peace advocate, with no hidden agenda but peace. The spirit of peace is the Holy Spirit of God. It can soar over ashes and shattered houses and give hope where seemingly there is none.

\section{Communication}

This strategy contributes to the achievement of peace through communication and dialogue (Thamgaraj 1999).

It is wise to consult, ask questions, and secure assistance regarding directions and goals from stakeholders, left, right and center. For the government consult with the different branches of government and with the people directly affected by conflict. For the MILF - consult with the Bangsamoro people, with the MNLF, and with the ARMM. I am not sure that any of these consultations were done -- and competently.

The so-called "fusion of horizons" is the expected outcome of this strategy. It can be done in three ways: direct bargaining with one another, mediation, and arbitration (Myers: 284). For the past 16 years at the macro-level, the Malaysian government has played a prominent role as the third party or mediator in the peace talks between the Philippine government and the Moro Islamic Liberation Front (MILF) (Iqbal 2004; Makabenta 2015). However, Quevedo, in his capacity as a long-time religious leader in the region, has also served as a highly respected "mediator" between the two parties. In early 2004, the United Nations Development Programme (UNDP) experts along with Muslim and Christian leaders approached Cardinal Quevedo and asked him to lead a group of eminent persons to serve as high-level intermediaries and advocates and facilitate the relevant conversations with regard to legislation, as well as the wider cause of a lasting peace in Mindanao. This led to the formation of a group called "Friends of Peace" which Quevedo eventually led (Kuma 2004). Through his initiatives, he helped facilitate dialogues between and among the stakeholders especially when the peace process had been derailed or reached an impasse. The dialogue and negotiations for peace cannot be closed prematurely.

Experience has shown that the negative outcomes due to the absence or lack of a line of communication between the two parties may never be underestimated. The peace process has been derailed and almost died because one or both of the parties failed to communicate.

There were many times when his words were said in direct reply to perceived misinformation and disinformation as well as to address deep-seated biases and prejudices and thus "restore rationality to the peace process." In the face of outrage and calls for an all-out war, he asked the parties to go back to the negotiating table to rehabilitate the peace process. He called for consultation and dialogue, information and education as the key to the acceptability of the ill-fated MOA-AD:

MOA-AD has a lot of ambiguity as well as questionable presentation. Muslims, Christians, Lumad would want such issues to be clarified, before saying yes or no to the consensus points. Perhaps, concepts need to be clearer. They can be made so in future steps of the peace process as both parties move towards a Comprehensive Pact. But the MOA-AD need not be the document that should contain all the details that would resolve all questions and doubts. The peace process will continue even after it is signed. With goodwill, patience and wisdom --- and consultation ---such further steps will surely resolve substantive questions.

Therefore, as a way out of the present impasse let organized and focused public discussions on the MOA-AD be conducted for a specific and reasonable time so that the two parties may be guided accordingly. In the face of possible provocations, be persevering, patient and resolute until a fair and just final peace agreement is done.

Because of misunderstanding and mistrust from both side of the divide, Quevedo strongly and many times suggested as an imperative: a serious and sustained effort to inform and educate all of the constituencies and stakeholders about "matter that is of utmost importance to them and their future" and about the mutual rights and mutual sacrifices needed by both parties."

There is certainly the imperative of educating all the various constituencies 
and stakeholders as to the contents (concepts and principles, territory, resources, and governance) of the MOA-AD, their bases in history and in law, the steps still to be taken, the recognition of mutual rights, as well as the mutual sacrifices needed by both peoples, Bangsamoro and non-Bangsamoro.

It would be to the interest of the common good for them (the peace panels) to explain the meaning and the rationale of provisions that are questioned and objected to.

Two immediate reasons for the negative reception of the MOA-AD are lack of information regarding the contents of the document and the lack of previous consultation with various stakeholders as to what the document should contain. No serious effort was made to establish a supportive public constituency. Having consultations, asking for directions, providing progress reports - these are proven ways to have people participate in any matter that is of utmost importance to them and their future.

The words synonymous to communication are plenty: information, dialogue consultations, consensus-building, and reception in its ecclesiological sense (Congar 1972). This study found that "consult" and "consensus" were Quevedo's most utilized words. Strongly believing that a genuine consensus is possible, he argued that all stakeholders must be allowed to voice their views and demanded the mutual respect and attention of all. Stressing the need for and importance of consensus-building through wide consultations, he said that:

But there is a certain irreplaceable and indispensable benefit to people's participation through consultation and information dissemination at various points in the peace journey. I am quite certain that both the MILF and the GRP have set a certain time for extensive consultations, perhaps when referendum and changes to constitution/law are to be made. But present reactions cannot wait for that time.

In the wake of the many incidents that tend to derail the peace process, Quevedo remained strongly committed to fostering a culture of dialogue, forging a unity of opinion - or consensus-based on all the above points through widespread consultations by both sides (Rosario-Braid 2000). In spite of the prevailing culture and history of mutual prejudices, he maintained this mindset throughout the search for peace.

Aggravated by lack of consultation and reinforced by anger, misinformation, misconceptions, biases, prejudices, and resistance to change, led to the present grave uncertainties regarding the peace process.

Due to lack of information resulting in the negative reception of the MOA Consultation, public discussions and dialogue with all the stakeholders are a must to arrive at a consensus on issues that divide. Reception of the peace process intended outcome is the result of this consultation.

One would think then that along the arduous and difficult journey, certain stops should be made to ask for directions, consult people, set goals and then obtain consensus points at the roadside negotiation table.

\section{Conciliation}

This strategy is designed to de-escalate tensions that may arise during the peacemaking between the two parties in conflict. This element of conciliation is based on what is nicknamed as GRIT or "graduated and reciprocated initiatives in tension reduction" (Myers: 291). Based on the belief that the participants are equal, it is not so much retaliatory as it is conciliatory in mode. It requires no preconditions to the conciliation or the surrender of one's original and non-negotiable position but only seeks a middle ground between the two opposing sides.

Three intervening events happened that threatened to derail the peace process, led to grave uncertainties, and compelled the urgent need to de-escalate the tensions triggered by them. They were the declaration by the Supreme Court Supreme that the MOA-AD as unconstitutional (August 2008), the Buliok war (February 2003), and the Mamasapano tragedy (March 2015). All three events re-escalated the conflict and triggered the deep historic biases and prejudices that lie in the dark corners of the two parties, Quevedo said. As a participant of the peace process, he only knew too well how volatile everything can be in the region and did try his best to conciliate between the adversaries. To reduce the tension, he immediately proposed small de-escalatory actions such as the need to 
conduct participatory fact-finding investigations and to return to the negotiating table. After the Mamasapano tragedy that seriously cast doubts on the peace process and increased the tensions, he said:

The demand for wisdom is for us to hold back the natural response of revenge and desire to break off the peace process. The bloodbath in Mamasapano should not end in the peace process in Mindanao.

To ease the tensions and resist the demoralizing results of the three events, he immediately proposed to establish verifiable conciliatory acts and challenged both parties to reciprocate without risking their security and selfinterests. As what exactly was needed at those tragic events, he earnestly proposed two steps to quickly bounce back and ease the pressure on the two sides: to return to the negotiating table and to organize focused public discussions on the MOA-AD for a specific and reasonable time.

It remains true that many things cannot be negotiated in public; otherwise, the plethora of opinions and suggestions, each one passionately presented and defended, would create disorder out of order. But there is a certain irreplaceable and indispensable benefit to people's participation through consultation and information dissemination at various points in the peace journey. I am quite certain that both the MILF and the GRP have set a certain time for extensive consultations, perhaps when referendum and changes to constitution/law are to be made. But present reactions cannot wait for that time.

\section{How did he say or do it?}

Quevedo's words were attempts to answer a fundamental question: What is the wise thing to do in a conflict situation like Mindanao? Three words may be used to explain this domain of his peacemaking task namely: practical wisdom, consensus-driven, and Catholic.

\section{Practical Wisdom}

The French philosopher Paul Ricoeur's concept of phronetic or practical wisdom would help make sense of Quevedo's integrative and balanced approach to the peace process (Vermeer and van der Ven 2002). For Ricoeur, practical wisdom is the ethical skill that helps one to determine the "good life with and for others in just institutions," test it against the "right norm," and strike a balance between the good and right in concrete situations." Applied to the concrete situation of the Mindanao conflict, the image of the "good life" would be the collective desire to achieve a long overdue peace in general, and the right to self-determination of the Muslims, in particular. To pass the critical test for the objectively good, however, the ethical aim needs to "pass through the sieve of the norm" as provided by the Constitutional requirement that seeks to protect the sovereignty and territorial integrity of the country. In line with Rosario-Braid's (2002) suggestions, Quevedo used constructive rather than adversarial communications; emphasized the commonalities rather than disagreements between the two adversaries, explored the multifaceted angles of a simple idea such as peace, justice, and progress.

Based on these concepts, it is clear that to succeed in his ministry as a peacemaker, it was imperative for Quevedo to carefully navigate between the Scylla of perpetuating a historical injustice and the Charybdis of dismembering the republic. Happily, he managed to stay on course and to strike a balanced and accurate account of the good life and the right norm is the concrete and complex situation of the Mindanao conflict.

\section{Consensus-Driven}

Following Jürgen Habermas' theory of communication, Quevedo's language and words about peace and its imperatives may be described as "that which seeks mutual understanding and possesses no strategic goal other than the achievement of a consensus or common understanding" of the "good life" and the norms of peacemaking (Gallardetz 2002). It was a consensus-driven dialogue for peace based on the maintenance and promotion of the dynamic relationships between and among the stakeholders and constituents. When faithfully engaged in, the model can yield "shared truth" of a fusion of horizons between the conflicting parties.

Quevedo employed this communication model as a reciprocal act of sharing in which the intended recipients from both sides will actively and selectively appropriate that which is communicated. As a type of dialogue or conversation, his approach was a communicative and not a strategic approach to peacemaking, not a top-down strategic kind of communication geared only towards a successful resolution of the conflict. On the contrary, it was deeply rooted in the ground and oriented towards a holistic understanding of the collective search for peace and justice. Quevedo's single-minded purpose was to guide stakeholders to a shared understanding of the conflict through constant dialogues, consultations, negotiations and reception of their shared resolutions to establish peace. 


\section{Catholic}

Finally, Quevedo's words manifest an approach that is clearly and distinctly "Catholic." It adopts the principle of complementarity, a this-as-well -as- that approach to reality and thus not dialectic either-or approach.

First, it adopts an integrative perspective of all the issues and challenges that had bedeviled the peace process across time. Second, both rooted in his religious tradition (the use of reason informed by faith) and yet open to the perspectives of the other, he saw to it that all the various constituencies and stakeholders were given a voice and a hearing whether they are left, right and center, whether they are Muslims, Christians or Lumads, the government, and the Bangsa Moro, MILF, MNLF. Third, he consistently and respectfully paid attention to their common and self-interests, fears and prejudices, misconceptions and misinformation. With his sight singly-focused on the common good, he painstakingly tried to be both inclusive and integrative in the firm hope of achieving the fusion of horizons between the Bangsamoro aspirations for self-determination and GRP conviction to its national sovereignty. For a deeper and wider understanding and appreciation of the issues and challenges that had beset it, his words put into light the historical, cultural, legal, political, territorial, economic, and social dimensions of the conflict. This has helped diminished the ambiguities, doubts, and prejudices surrounding the peace process.

\section{How did He Keep Going? What Kept Him Going?}

It is a commonly known fact that peacemaking is a challenging and complex task. It is surely not for the fainthearted. Amid the clear and present risks to their lives and limbs, peacemakers will need a lot of daring, courage, patience and optimism that at the end of the long and tedious path peace will be realizable. Holbrooke said that it takes some qualities to be a peacemaker in a world torn apart by intractable conflicts: diligence and persistence, unique insight, credibility, passion, and a commitment to the idea that peace is possible. We may add courage to face the possibility of torture and death. Not a few of our local peacemakers have lost their lives without seeing the peace and justice that they dreamed and pursued the people of Mindanao. This sad reality makes us wonder: "What has kept peacemakers like Cardinal Quevedo going against the many odds of peacemaking?" What is his secret? In the seeming absence of manifest answers from his testimonies, we may therefore only make an educated guess: the secret lays both in the human and divine domains of peacemaking.

Following Holbrooke's assessment of what enables individuals to be a peacemaker, I think it is in Quevedo's "moral conviction and religious calling to work until peace and justice are a reality" where his secret lies. Moral conviction is defined as "a subjective assessment that one's attitude about a specific issue or situation is associated with one's core moral beliefs and fundamental sense of right or wrong" (Bauman and Sitka 2003). It is the subjective belief that something is fundamentally right or wrong which Quevedo strongly asserted consists of the historical and social injustice that the Muslims endured and suffered for centuries. Although it seems an unpopular idea, he is morally convinced that unless the historical injustice and the basic rights of the Muslims for selfdetermination are resolved through a principled negotiation between the two parties, the just and sustainable peace will most likely not come to Mindanao.

As a religious leader and a Christian disciple, there is no doubt as to the second possible reason why Quevedo kept going in spite of the seemingly insurmountable obstacles to peacemaking. He has said many times that he is into this advocacy because of his religious calling both as a parish priest and later on as an archbishop of a diocese that is $47 \%$ Muslim and $48 \%$ Catholic. Although he believes that peace is God's grace and gift, he is also convinced that for peace to become a reality he must perform his task as a Christian and as a leader of his flock.

Because peace is both gift and task. Ultimately it is a gift of God. But it is also our task. It is our task to be peacemakers rather than to be destroyers of peace. That we do not have peace is due to us. We have not done our task.

I beg you as fellow disciples of Christ, the Prince of Peace, to pray and work together for peace so that Mamasapano will not repeat itself.

It is the Spirit of God that gives hope and infuses love and harmony among peoples of different faiths and cultures. With God's Spirit, we can soar over tragedies, we can restore trust for one another; we can strive together for harmony and peace. Ultimately it is in the enlightened heart where love and peace begin. May the God of Justice, Peace and Love bless us all!

He has always prayed for peace knowing that, regardless of his own human efforts peace, his faith tells him that it would ultimately remain a gift of God's grace and mercy. In short, he is a peacemaker because he is a man of prayer, a man of faith, and ultimately a man of God.

I am for peace, the peace that God grants to people of goodwill. I am for the 
peace that God gives through the collaborative work of men and women who work conscientiously for the good of the whole country.

\section{Conclusion and Research Directions}

This study focused on Orlando Cardinal Quevedo's advocacy for peace and its imperatives in the Southern Mindanao region. A close and careful examination of his statements makes manifest an eyewitness understanding of the historical roots of the armed conflict and a comprehensive plan of action to uproot it to gain a just and sustainable peace in the region. It is crystal-clear that he knew exactly what he was doing and speaking about for years on end. Moreover, they also speak volumes about his practical wisdom as well as his courage to "fight the good fight" even in the face of humanly insurmountable obstacles and risks to his life. Though bereft of political power and armed only with his religious faith and moral conviction, he proved to be a credible and attractive voice in the public square where the choice between war and peace and life and death were being decided.

As an advocate of peaceful strategies to make and build peace in Southern Mindanao, the extent of his influence and impact on the peace process may not be exactly measured. But by organizing and analyzing his words about peace and its demands, the long-running conflict is better understood and the issues and challenges standing in the path of a just and sustainable peace in the island cleared and flattened. The lessons and insights that this exploratory study has helped uncover may serve as a grounded recipe for future peacemakers to learn and re-appropriated in a hopefully not an unending task and ministry of peacemaking in today's world.

Cardinal Quevedo's case is merely illustrative though; there is a need to examine more closely the narratives of the other few good men and women who, like him, have courageously and selflessly performed the task and ministry of peacemaking and peace-building in the region. It will help would-be-peacemakers to better understand not only "who they are, what they do, how they do it, and what keeps them going" but also the fundamental challenges and opportunities facing the thousand-mile journey toward a just and lasting peace in Mindanao.

\section{References}

\section{A. Articles in a print and online-only journal}

Abreu, L. M. (2008). Ancestral domain-the core issue. Moro Reader, 56.

Bacongco, K. (2010). "Buliok 7 years after the war: Painful imprints still linger". Available online at MindaNews.

Brady, C., Agoncillo, O., Butardo-Toribio, M. Z., Dolom, B., \& Olvida, C. V. (2013). Improving natural resource governance and building peace and stability in Mindanao, Philippines. Livelihoods, natural resources, and post-conflict peacebuilding.

Clark, J. (2008). Philosophy, Understanding, and the consultation: a fusion of horizons. British Journal of General Practice 2008 January 1, 58(546), 58-60. https://doi.org/10.3399/bjgp08X263929

Congar, Yves-Marie (1972). Reception as an Ecclesiological Reality. Concilium (GB), 77, 43-68.

David, R. (2018). Duterte's Language-Games. Philippine Daily Inquirer, Public Lives August 19, 2018, Available (a) inquirerdotnet

De Jesus, Edilberto (2018). Birthing the Bangsa Moro Autonomous Region. Philippine Daily Inquirer, November 03, 2018. Available at inquirerdotnet.

Mohammad, I. (2012). Peace Talk: Malaysia and Its Role in the GPH-MILF Peace Process. Retrieved from http://www.mindanews.com

Jayawardena, Shanil, O. M. I. (2014). Interview with Cardinal Orlando B. Quevedo. General House, Rome. Available at https://www.omiworld.org/interview/cardinal-orlando-b-quevedo-omi/

Makabenta, Y. (2015). Malaysia's Role Should be explained. Retrieved from https://www.manilatimes.net/malaysias-role-should-be-explained/177169/

Mercado, Eliseo, O. M. I. (2014). Cardinal Quevedo: A Prophet in Mindanao. Retrieved from https://www.rappler.com/.../47815-philippines-orlando-quevedo-cardinal- Mindanao

Rosario-Braid, F. (2000). The Lessons of the Philippine Peace Process. Retrieved from http://www.muslimmindanao.ph/peace_process/the $\% 201$ essons $\% 20 \mathrm{of} \% 20$ the $\% 20$ phil $\% 20$ peace $\% 20$ process .pdf 
Vermeer, Paul, and van der Ven, Johannes (2002) A Students' Moral Consciousness. Journal of Empirical Theology, 15(2002), 54-75.

Vitug, M. (2004). A Peacemaker on Mindanao, Newsweek. Retrieved from atwww.newsweek.com/peacemakermindanao-168784

\section{B. Chapter in a Book}

Gallardetz, R. (2002) The Reception of Doctrine: New Perspectives, from Authority in the Roman Catholic Church. Bernard Hoose (Ed). Ashgate.

Holbrooke, R. (2007) Preface to Peacemakers in Action: Profiles of Religion in Conflict Resolution. David Little (Ed). Tenenbaum Center for Interreligious Understanding. Cambridge University Press.

Stephens, M. (2016) Mindanao: The Long Journey to Peace and Prosperity. Paul D. Hutchcroft (Ed). Anvil Publishing Inc.

\section{Books}

Allen Nan, S., Mampilly, Z. C., \& Bartoli, A. (2001). Peacemaking: From Practice to Theory. Volume 1. Praeger.

Fernandez, P. O. P. (1979). History of the Church in the Philippines (1521-1898). Metro Manila: National Book Store.

Fraenkel, J., \& Wallen, N. (2013). How to Design and Evaluate Research in Education. McGraw-Hill Inc.

Gadamer, Hans-George (2004). Truth and Method. 2nd revised ed. London: Continuum International Publishing Group.

Myers, D. (1994). Exploring Social Psychology. McGraw-Hill, Inc.

Thangaraj, Thomas (1999). The Common Task: A Theology of Christian Mission. Nashville: Abingdon Press.

\section{Thesis or Dissertation}

Aquino, R. M. (2009). Land ownership and migration impact on the Muslim secessionist conflict in the Southern Philippines (Doctoral dissertation, Monterey, California: Naval Postgraduate School).

David, R. A. (2003). The causes and prospect of the southern Philippines secessionist movement (Doctoral dissertation, Monterey, California. Naval Postgraduate School.

Luga, A. R. (2002). Muslim Insurgency in Mindanao, Philippines. Army Command and General Staff College Fort Leavenworth KS.

\section{Notes}

Note 1. With his expressed permission, the data and information gathered for purposes of this study were mostly sourced or cited from Cardinal Quevedo's communications such as letters, interviews as well as newspaper and journal articles from 2005-2017 accessed from his blog archive http://abpquevedo.blogspot.com.

Note 2. Interview with Shane Healy, July 2017. Available at https://youtu.be/SV3AVYuwKT8

Note 3. Two major wars occurred while Quevedo was President of the Catholic Bishops Conference of the Philippines for two-year terms (1999 to 2003: the Estrada administration's "all-out war" in 2000 which displaced nearly a million residents and the Arroyo administration's 2003 Buliok war which displaced nearly half a million residents. Both wars occurred amid peace talks. (MindaNews/05 February). More recently, the Mamasapano tragedy happened when the MOA-AD was about to be signed into law by the government.

Note 4. From an Interview with Thomas Rosica, CSB. March 9, 2017. Available at https://youtu.be/xnBIrdd-vpw

\section{Biographical Statement}

Noel G. Asiones earned his Ph.D. in Theology and M.A. in Psychology from the University of Santo Tomas, Manila, Philippines, in 2005 and 1999 respectively. He teaches fundamental college Theology with the Institute of Religion and is a researcher at the Research Centre for Social Sciences and Education. His field of interests includes religion and youth, organizational assessment and evaluation, and church and social issues. He has done commissioned and national research projects for the Catholic Bishops' Conference of the Philippines-Episcopal Commission on Youth (CBCP-ECY) and the Catholic Educational Association of the Philippines. As one of its 
co-authors, his most current published research for the CBCP-ECY is titled "The National Filipino Catholic Youth Survey 2014."

Email address: ngasiones@ust.edu.ph

\section{Copyrights}

Copyright for this article is retained by the author(s), with first publication rights granted to the journal.

This is an open-access article distributed under the terms and conditions of the Creative Commons Attribution license (http://creativecommons.org/licenses/by/4.0/). 